\title{
BMJ Open The relationship between job satisfaction, work stress, work-family conflict, and turnover intention among physicians in Guangdong, China: a cross-sectional study
}

\author{
Yong Lu, ${ }^{1}$ Xiao-Min Hu, ${ }^{2}$ Xiao-Liang Huang, ${ }^{3}$ Xiao-Dong Zhuang, ${ }^{4}$ Pi Guo, ${ }^{1}$ \\ Li-Fen Feng, ${ }^{3}$ Wei Hu, ${ }^{3}$ Long Chen, ${ }^{3}$ Huachun Zou, ${ }^{1}$ Yuan-Tao Hao ${ }^{1}$
}

To cite: Lu Y, Hu X-M,

Huang $X-L$, et al. The relationship between job satisfaction, work stress, workfamily conflict, and turnover intention among physicians in Guangdong, China: a crosssectional study. BMJ Open 2017;7:e014894. doi:10.1136/ bmjopen-2016-014894

- Prepublication history and additional material are available. To view these files please visit the journal online (http://dx.doi.org/ 10.1136/ bmjopen-2016-014894).

Received 26 October 2016 Revised 10 February 2017 Accepted 22 March 2017

CrossMark

For numbered affiliations see end of article.

Correspondence to Dr Xiao-Min Hu; xmhu@ieee.org and Xiao-Liang Huang; huxiaom6@mail.sysu.edu.cn

\section{ABSTRACT}

Objective To investigate the relationship between job satisfaction, work stress, work-family conflict and turnover intention, and explore factors associated with turnover intention, among physicians in Guangdong Province, China. Methods From August to October 2013, physicians completed questionnaires and scales with regard to their job satisfaction, work stress, work-family conflict, and turnover intention. Binary logistic regression and structural equation modelling (SEM) were used in data analysis.

Results A total of 3963 physicians were approached, with 3563 completing the questionnaire. The mean score of the overall perception of turnover intention of physicians who worked in Guangdong was 2.71 on a scale ranging from 1 to 6 . Hours worked per week, working in an urban/rural area, type of institution, and age significantly impacted on turnover intention. Turnover intention was directly and negatively related to job satisfaction, and it was directly, indirectly and positively related to work stress and workfamily conflict.

Conclusion Job satisfaction, work stress, work-family conflict, hours worked per week, working in an urban/rural area, types of institution and age are influencing factors of turnover intention. Reducing working hours, raising salary, providing more opportunities for career development and training, supporting and encouraging physicians by senior managers could potentially contribute to the reduction in turnover intention.

\section{INTRODUCTION}

In 2009, the number of physicians per 10000 population was 16 in Guangdong Province in southern China, ${ }^{1}$ smaller than the average of 17.5 in China. ${ }^{2}$ According to WHO statistics," the number of physicians per 10000 population was 24.2 in the United States in 2009. An insufficient supply of health workers has been a long-existing problem in Guangdong.

Turnover intention is defined as the probability that an employee will leave his or her job within a certain time period. ${ }^{4}$ Since March and Simon ${ }^{5}$ proposed a participant

\section{Strengths and limitations of this study}

- This study was the first to investigate the turnover intention of physicians in Guangdong with a large sample of 3563 physicians since the inception of health system reforms in 2009.

- This study used structural equation modelling to quantify the impact of different perceptions and to distinguish direct and indirect effects on turnover intention.

- The questionnaire in this study might not be suitable for other research.

- Since it was a cross-sectional study, the causal relationships between influencing factors and turnover intention could not be determined.

determination model on turnover in 1958 , different models on turnover have been proposed, ${ }^{6-13}$ focusing on the linkages of factors, turnover behaviours, and turnover intention, etc. Among these models, turnover intention was regarded as one of the best predictors of turnover behaviours and it could explain a certain amount of variance in turnover behaviours. ${ }^{14}$

High turnover intention in physicians has become a critical problem in the development of the healthcare system. More than half of Iraqi doctors $(55.2 \%)$ had turnover intention because of poor working conditions and serious security concerns. ${ }^{15}$ Due to ineffective human resource management practices, $69 \%$ of health workers were reported to have turnover intentions in Ghana. ${ }^{16}$ In China, Li et al ${ }^{17}$ disclosed that about half of clinical physicians in public hospitals had turnover intention because of concerns about burnout, lack of support and chance of promotion. A survey implemented in Liaoning Province, China indicated that $41.4 \%$ of physicians intended 
to leave their workplace because of high work stress. ${ }^{18}$ An investigation in Xiangyang City, Hubei Province showed that over one-third $(36.8 \%)$ of village doctors had turnover intention and revealed that job satisfaction had an impact on turnover intention. ${ }^{19}$ Based on a self-developed questionnaire, a survey conducted in Hubei Province revealed that physicians from urban state-owned medical institutions had a mean score of turnover intention of 3.18 (neutral) out of 5 and indicated that job satisfaction and burnout were influencing factors for turnover intention. ${ }^{20}$ Tsai $e t a l^{21}$ showed that $14.5 \%, 30.0 \%$ and $55.5 \%$ of physicians in Taiwan had strong, moderate and mild intention to leave their current hospital. Since education and training for physicians takes a long time, high turnover intention will add to the already-existing shortage in physicians. A chain of consequences will take place, including increased workload for physicians, compromised medical service quality, and strained physician-patient relationships. In the US it has been estimated that the turnover cost at a major medical centre might be more than $5 \%$ of the total annual operating budget, due to recruitment and training costs and productivity loss. ${ }^{22}$ Measures should be taken to prevent turnover to ensure the stability of the physician team.

However, turnover intention is always affected by various aspects, for example job strain, ${ }^{23}$ workplace violence, ${ }^{24}$ physician burnout, ${ }^{25}$ job satisfaction, ${ }^{26}$ income, ${ }^{21}$ organisational commitment, ${ }^{27}$ among others. Job satisfaction was one of the earliest proposed and frequently mentioned influencing factors for turnover intention. ${ }^{14}$ A study of Iraqi doctors found low job satisfaction was associated with turnover intention (OR=0.97, 95\% CI 0.95 to 0.99$){ }^{15}$ Most researchers reported that job satisfaction highly influenced turnover intention. ${ }^{28}{ }^{29}$ However, not all items of job satisfaction have a relationship with turnover intention. $\mathrm{Gu}$ et $a l^{14}$ reported that there were no relationships between social status satisfaction $(r=-0.041, \mathrm{p}=0.32)$, work conditions satisfaction $(r=-0.017, \mathrm{p}=0.68)$, physicianpatient relationship satisfaction $(r=-0.070, \mathrm{p}=0.09)$, and turnover intention among physicians.

Work stress is defined as an employee's reaction to characteristics at the workplace that seem mentally and physically threatening. ${ }^{30} \mathrm{~A}$ high level of work stress could make employees unhealthy, poorly motivated, less productive, and less safe at work. ${ }^{31}$ Work stress not only affects their health but also their work performance, leading to absences or turnover. Work stress is widely regarded as one of the influencing factors of job satisfaction. A series of studies revealed that work stress was negatively correlated to job satisfaction, ${ }^{32-38}$ whereas some studies disclosed that work stress had a positive effect on turnover intention. ${ }^{39-41}$

Work-family conflict is defined as a form of inter-role conflict that will appear when it is difficult to balance the pressure of work and family. ${ }^{42}$ The three main types of work-family conflict are time based, strain based and behaviour based. ${ }^{43}$ Some research in other countries indicated that work-family conflict could positively affect turnover intention. ${ }^{445}$ Some studies reported that there were neither direct nor indirect relationships between work-family conflict and turnover intention. ${ }^{46}$ Armstrong et $a l^{47}$ indicated that work-family conflict was significantly related to both work stress and job satisfaction. ${ }^{47}$

Up till now, there was no study on turnover intention among physicians in Guangdong since the most recent health system reform (2009-2012). The reform involved the increase of health insurance coverage, the introduction of an essential drug list, fixed salaries for health workers set by the local government, and improvement in the delivery of public health services in primary care. ${ }^{48} 49$ One priority of the reform was to provide medical insurance to at least $90 \%$ of the population of China. ${ }^{50}$ The reform also aimed to improve medication availability, quality, rational use, and to establish a national essential medicines system. Although the reform made health resources more available, there was an increase in workload for physicians. Before the salary reform, drug sales were the main source of income for medical institutions and physicians' income was directly related to the profits of their prescriptions. After the salary reform in 2009, a fixed basic salary and performance-based bonus were introduced to replace the previous income sources. According to Wu et al and Zhou et al, ${ }^{48}{ }^{49}$ after the reform, physicians in poor areas might be able to enjoy a higher income and financial stability, and those in wealthy areas might have a serious salary reduction. However, salary in poor areas was still lower than that in wealthy areas. It is necessary to investigate the turnover intention after the health system reform.

The purposes of this study were: (1) to assess the turnover intention of physicians in Guangdong after the recent reforms and (2) to explore the relationship between turnover intention and job satisfaction, work stress and work-family conflict.

\section{METHODS}

\section{Participants and sampling}

Based on the available official data, there were 192107 physicians in Guangdong Province, China in 2012, including assistant practising physicians. ${ }^{1}$ The data used in this study were from the Fifth National Health Service Survey in Guangdong Province. All physicians who had a practising qualified certificate on file were eligible for admittance to this study.

The sample size in this study was evaluated by $n_{c}=\frac{n_{1}}{1-n_{1} / N}, \quad$ where $n_{1}=n \times \operatorname{deff}, \quad n=\left(\frac{Z_{\alpha / 2} \sigma}{\delta}\right)^{2}$ with $\alpha=0.05, Z_{\alpha / 2}=1.96$, estimate of $\mathrm{SD} \sigma=1.31$, allowance error $\delta=0.05$, design effect deff=1.2, $\mathrm{n}=192107$. Here, is the sample size after the design effect correction to the calculated sample size $n$. After finite population sampling correction, $n_{c}$ is the final sample size. The values of $\sigma$ and deff were obtained based on the results of the Fourth National Health Service Survey in Guangdong Province. ${ }^{205152}$ The value of $n_{c}$ was computed as 3217 , and the sample size should not be smaller than this figure. In this 
study, a total number of 3963 physicians in Guangdong Province were selected to participate in the survey.

The method of multistage stratified cluster random sampling was adopted to acquire the sample. First, 40 sample districts and counties from 21 prefecture-level cities of Guangdong province were randomly selected. Second, all tertiary hospitals and some of the secondary hospitals were selected as sample units. At the same time, 200 towns/ streets and 400 villages/neighbourhoods were chosen randomly. All community health service centres and health clinics in the selected 200 towns/streets and 400 villages/ neighbourhoods were chosen as sample units. Third, the sample group was selected from each sample unit (20 physicians per hospital, seven physicians per community health service centre/health clinic) by simple random sampling. If the real number of physicians in the institution was not enough, all physicians were selected.

\section{Measuring instruments}

The questionnaire was produced by the National Health and Family Planning Commission, consisting of eight parts along with a covering letter outlining the survey objective and reply methods. ${ }^{53}$ The questionnaire related to this study contained the following five sections: basic socio-demographic information, job satisfaction, work stress, work-family conflict, and turnover intention.

Section 1 consisted of basic socio-demographic information: gender, age, marital status, education background, professional status, occupation, years of service, type of institution, employment status, administrative duties, department, hours worked per week, night shift frequency (per month), annual income, working in urban/rural area, working in Pearl River Delta or not. The regions in Pearl River Delta are considered part of an emerging megacity, which is more prosperous than the other regions in Guangdong. In China, a bachelor's degree in medicine is an undergraduate academic degree awarded by colleges and universities on completion of a course of study lasting 5 years. A college degree is a qualification awarded on successful completion of a course of study that continues for 3 years in junior college. Lower than junior college includes technician training school, senior high school and junior high school, etc.

Sections 2-5 were the variables measured. Job satisfaction includes eight items developed from the Job Descriptive Index (JDI) ${ }^{54}$ that is, colleagues, the work itself, promotions, remunerations, environment, facility, superiors and current job. An example of the item format is 'I'm very satisfied with my superiors'. Work stress includes four items, that is, feel great pressure from work, feel a high level of tension from work, have trouble falling asleep because of work, feel nervous because of work. These items were adapted from the report. ${ }^{55}$ Turnover intention includes four items, that is, thought of leaving the organisation you served now, thought of leaving this industry, looking for a new job recently, looking for a new job next year. They were selected from a questionnaire developed by Cammann et $a l^{56}$ and Mobley. ${ }^{57}$ Work-family conflict was assessed using a nine-item work-family questionnaire developed by Carlson. ${ }^{58}$ The job satisfaction, work stress and turnover intention dimensions included 16 items on a six-point Likert scale ranging from 1 (highly disagree) to 6 (highly agree). The work-family conflict was assessed on a five-point Likert scale ranging from 1 (highly disagree) to 5 (highly agree).

Although the questionnaire has been used in the pilot pre-survey, this survey is the first large-scale use of this questionnaire. Therefore, it is necessary to investigate the reliability and validity of the questionnaire. Exploratory factor analysis (EFA) based on principal components for the dimensions on the formal samples showed that four factors were extracted (table 1). According to previous studies ${ }^{59-61}$ factor loading values at 0.3 or greater were considered acceptable, whereas those greater than 0.55 were considered good. table 1 showed that all the loading values of the items to the corresponding dimensions were greater than 0.55 , so the construct validity of the questionnaire was good.

In order to analyse whether the four one-factor models could be appropriately supported by the investigation data, the confirmatory factor analysis (CFA) based on structural equation modelling (SEM) was performed on the samples. We used latent variables and manifest variables (items) to construct a SEM to investigate the construct validity of the questionnaire. The values of goodness of fit index (GFI), adjust goodness of fit index (AGFI), normed fit index (NFI), comparative fit index (CFI), incremental fit index (IFI), Tucker-Lewis incremental fit index (TLI), root mean square error of approximation (RMSEA), and root mean square residual (RMR) are shown in table 2. The magnitudes of these indices were evaluated according to the recommendations of $\mathrm{Hu}$ and Bentler. ${ }^{62}$ The model will be considered to be adequate when GFI, AGFI, NFI, CFI, TLI, IFI $>0.90$, RMSEA $<0.08$, RMR $<0.10$. The model will be very good if GFI, AGFI, NFI, CFI, TLI, IFI $>0.95$, RMSEA $<0.05$. It could be observed that the model was good based on all the values of the above indices. The EFA and CFA results showed that the survey instruments had good construct validity. Additionally, the Cronbach $\alpha$ coefficients $^{63}$ reflecting the internal consistency were from 0.870 to 0.930 for these dimensions (table 1 ), indicating a good level of reliability.

\section{Data collection}

A cross-sectional survey was carried out from August to October 2013 in all selected sample units. Participants self-administered a questionnaire and scales. Each health bureau was responsible for the training of investigators, who regained completed questionnaires under detailed inspections on the spot to ensure the quality of the questionnaires.

The Ethics Review Committee of the Health Department of Guangdong Province approved the study protocol. All participants in the study had provided written informed consent before participating in this survey. Participation was voluntary and anonymous. 
Table 1 Factor loading of items using the exploratory factor analysis (EFA) and cronbach $\alpha$ of difference dimensions

\begin{tabular}{|c|c|c|c|c|}
\hline & $\begin{array}{l}\text { Job } \\
\text { satisfaction }\end{array}$ & $\begin{array}{l}\text { Work } \\
\text { stress }\end{array}$ & $\begin{array}{l}\text { Work-family } \\
\text { conflict }\end{array}$ & $\begin{array}{l}\text { Turnover } \\
\text { intention }\end{array}$ \\
\hline Colleagues & 0.591 & & & \\
\hline The work itself & 0.736 & & & \\
\hline Promotions & 0.771 & & & \\
\hline Remunerations & 0.769 & & & \\
\hline Environment & 0.776 & & & \\
\hline Facility & 0.759 & & & \\
\hline Current job & 0.841 & & & \\
\hline Superiors & 0.649 & & & \\
\hline Feel great pressure from work & & 0.844 & & \\
\hline Feel a high level of tension from work & & 0.861 & & \\
\hline Trouble falling asleep because of work & & 0.853 & & \\
\hline Feel nervous because of work & & 0.854 & & \\
\hline Work keeps me from family activities & & & 0.787 & \\
\hline $\begin{array}{l}\text { Time I devote to job keeps me from participating in household } \\
\text { activities }\end{array}$ & & & 0.830 & \\
\hline Miss family activities due to work & & & 0.837 & \\
\hline Problem-solving behaviours make no sense at home & & & 0.761 & \\
\hline $\begin{array}{l}\text { Behaviour that is effective and necessary at work would be } \\
\text { counterproductive at home }\end{array}$ & & & 0.706 & \\
\hline $\begin{array}{l}\text { Behaviours make me effective at work do not help me to be a better } \\
\text { parent or spouse }\end{array}$ & & & 0.774 & \\
\hline Too frazzled to participate in family activities & & & 0.844 & \\
\hline Drain prevents me from contributing to family & & & 0.858 & \\
\hline $\begin{array}{l}\text { Owing to the pressures from work, I do not want to do favourite } \\
\text { things at home }\end{array}$ & & & 0.806 & \\
\hline Thought of leaving the organisation you served now & & & & 0.877 \\
\hline Thought of leaving this industry & & & & 0.863 \\
\hline Looking for a new job recently & & & & 0.921 \\
\hline Looking for a new job next year & & & & 0.835 \\
\hline Average variance extracted (AVE) & 54.789 & 72.795 & 76.502 & 64.273 \\
\hline Cronbach's $\alpha$ & 0.881 & 0.870 & 0.930 & 0.897 \\
\hline
\end{tabular}

\section{Statistical analysis}

First, a $\chi^{2}$ test was conducted to compare the difference between the socio-demographic information from invalid questionnaires and valid questionnaires. The results indicated whether there was significant difference between them. Then we undertook a descriptive analysis of physicians' basic socio-demographic characteristics, job satisfaction, work stress, work-family conflict and turnover intention. For categorical variables, frequencies and percentages were used. For continuous variables, means and SD were used.

\begin{tabular}{lcccccccc}
\hline \multicolumn{1}{l}{ Table 2 Results of confirmatory factor analysis } & AGFI & GFI & NFI & CFI & IFI & TLI & RMSEA & RMR \\
\hline Recommended value & $>0.90$ & $>0.90$ & $>0.90$ & $>0.90$ & $>0.90$ & $>0.90$ & $<0.08$ & $<0.10$ \\
Job satisfaction & 0.954 & 0.983 & 0.983 & 0.983 & 0.983 & 0.964 & 0.071 & 0.050 \\
Work stress & 0.992 & 0.999 & 0.999 & 0.999 & 0.999 & 0.997 & 0.036 & 0.005 \\
Work-family conflict & 0.951 & 0.977 & 0.986 & 0.986 & 0.986 & 0.951 & 0.068 & 0.058 \\
Turnover intention & 0.983 & 0.998 & 0.999 & 0.999 & 0.999 & 0.993 & 0.055 & 0.014
\end{tabular}

AGFI, adjusted goodness of fit index; CFI, comparative fit index; GFI, goodness of fit index; IFI,incremental fit index; NFI,normed fit index; RMR, root mean squareresidual; RMSEA, root mean square error of approximation; TLI, Tucker-Lewis incremental fit. 
Binary logistic regression with a stepwise selection approach was employed to examine whether the items of job satisfaction, work stress and work-family conflict dimensions could significantly affect turnover intention, with the socio-demographic characteristics simultaneously used as controlled variables.

Physicians with an average score greater than 3.5 for turnover intention were classified as the 'high turnover intention' (1) group; the rest were 'low turnover intention' $(0)$. The following statistics in the binary logistic model were reported: Hosmer-Lemeshow test, Cox \& Snell R2, Nagelkerke $\mathrm{R}^{2}$, OR and $95 \% \mathrm{CI}$ with a $\mathrm{p}$ value. The above analyses were conducted using SPSS 20.0. p-values $<0.05$ were considered to be statistically significant in all analyses.

The relationship between job satisfaction, work stress, work-family conflict, turnover intention, and the fitness of the hypothetical model were verified via SEM. The SEM using maximum likelihood estimation was conducted by SPSS/AMOS 17.0. SEM ${ }^{64}$ is a method that allows the simultaneous estimation of all relationships between observed (manifest or unmeasured) and unobserved (or latent) variables of a model. It uses rectangles to represent manifest variables and circles to represent latent variables. An assumed causal path between two variables is represented by a one-way arrow. Path coefficients on the arrows are standardised partial regression coefficients, which indicate the effect of one variable on another, while controlling all other variables in the model. All coefficients without a sign reveal a positive association, whereas those with a minus sign show a negative association. Model fit was evaluated using GFI, AGFI, NFI, CFI, IFI, RMSEA, RMR and TLI.

\section{Hypothetical model and hypothesis}

The hypotheses applied to the model were tabulated as follows:

Hypothesis 1: Job satisfaction will negatively influence turnover intention.

Hypothesis 2: Work stress will positively influence turnover intention.

Hypothesis 3: Work stress will negatively influence job satisfaction.

Hypothesis 4: Work-family conflict will positively influence turnover intention.

Hypothesis 5: Work-family conflict will negatively influence job satisfaction.

Hypothesis 6: Work-family conflict will positively influence work stress.

\section{RESULTS}

\section{Socio-demographic information of participants}

A total of 3963 paper questionnaires were delivered to physicians, all of which were returned. After reviewing, 400 copies were incomplete or blank, resulting in 3563 valid responses and a response rate of $89.91 \%$.

The socio-demographic information of participants and distribution of dimensions are presented in table 3.
In the samples, $37.9 \%$ were women and $62.1 \%$ were men. The largest proportion of respondents $(43.8 \%)$ was in the 19-34 age group, followed by the 35-44 age group $(34.7 \%)$. The average age of the respondents was 37.6 \pm 8.5 years. Respondents' average years of service were 14.2 \pm 9.5 years. Most of the respondents had obtained a bachelor's degree $(57.6 \%)$, followed by junior college $(21.0 \%)$. Most respondents were resident physicians (39.5\%), followed by attending physicians (30.6\%). The majority of the respondents worked in hospitals (62.4\%), 20.5\% at community health service centres and the remaining $17.1 \%$ at health clinics. Additionally, $68.5 \%$ of respondents worked more than 40 hours per week and 58.9\% had at least four night shifts (per month).

\section{Effect of job satisfaction, work stress and work-family conflict on turnover intention}

The item scores of the survey were shown in table 4 . The item scores of job satisfaction, work stress, and turnover intention were from 3.03 to $4.71,3.52$ to $4.91,2.21$ to 3.01, respectively, whereas the overall mean scores of overall perception were $3.93,4.17$ and 2.71 , respectively. The item scores of work-family conflict ranged from 3.30 to 3.93 , and the overall mean score of overall perception was 3.65.

table 5 tabulates the results of binary logistic regression. The binary logistic regression model had goodness-of-fit under the Hosmer-Lemeshow test $\left(\chi^{2}=10.755, \mathrm{p}=0.216\right)$. For the socio-demographic variables, hours worked per week, working in an urban/rural area, type of institution, and age contributed significantly to turnover intention ( $\mathrm{p}<0.05$ for all). The model showed that promotions satisfaction $(\mathrm{OR}=0.836, \mathrm{p}<0.001)$, remunerations satisfaction $(\mathrm{OR}=0.896, \mathrm{p}=0.009)$, current job satisfaction $(\mathrm{OR}=0.628$, $\mathrm{p}<0.001)$, and superior satisfaction $(\mathrm{OR}=0.894, \mathrm{p}=0.006)$ for the job-satisfaction dimension; trouble falling asleep because of work $(\mathrm{OR}=1.140, \mathrm{p}=0.008)$, feel nervous because of work $(\mathrm{OR}=1.480, \mathrm{p}<0.001)$ for the work stress dimension; and items in the work-family conflict dimension such as 'behaviour that is effective and necessary at work would be counterproductive at home' ( $\mathrm{OR}=1.174$, $\mathrm{p}=0.004$ ), 'behaviour makes me effective at work do not help me to be a better parent or spouse' $(\mathrm{OR}=1.176$, $\mathrm{p}=0.002$ ), and 'owing to the pressures from work, I do not want to do favourite things at home' $(\mathrm{OR}=1.171, \mathrm{p}=0.002)$ proved to be significant to turnover intention under the control of socio-demographic variables.

Physicians who worked 40-56hours per week were 1.374 times more likely to have turnover intention, in comparison to those who worked $0-40$ hours per week $(\mathrm{p}=0.006)$. Physicians who worked in rural areas had a greater likelihood of turnover intention, in comparison to those who worked in urban areas $(\mathrm{OR}=1.269$, $\mathrm{p}=0.016)$. Compared with the physicians who worked in hospitals, physicians who worked in community health service centres were 1.353 times more likely to have turnover intention $(\mathrm{p}=0.016)$ and physicians who worked in health clinics were 1.482 times more likely to have turnover intention $(\mathrm{p}=0.002)$. The turnover intention of physicians 
Table 3 Socio-demographic information of the participating physicians

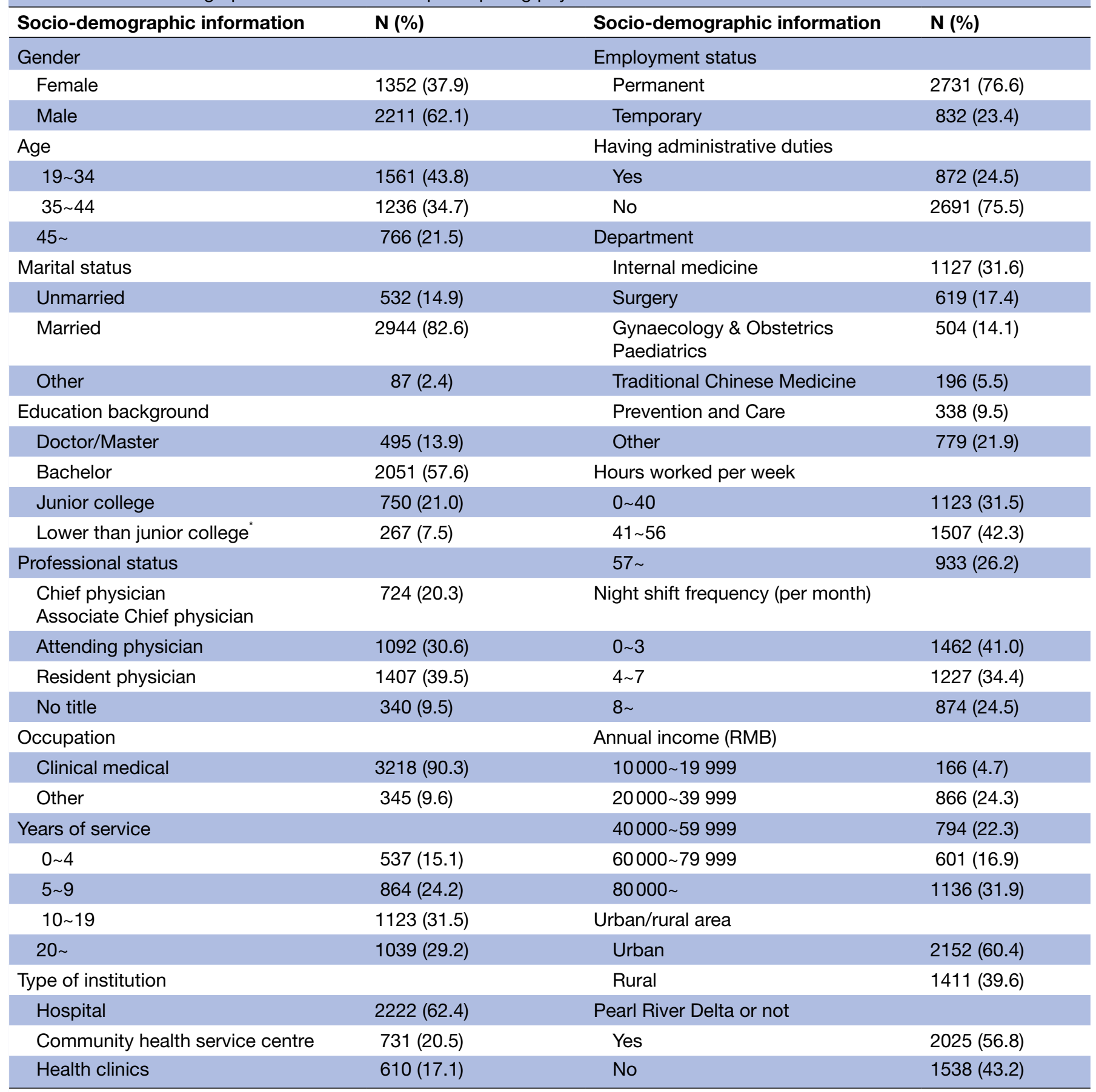

*Lower than junior college includes technician training school, senior high school and junior high school, etc.

who were older than 45 years was lower than those aged 19-34 (OR=0.753, $\mathrm{p}=0.028)$.

\section{Test of study models}

We used the SEM to quantify the relationship between the four dimensions. The overall model fit indices of the hypothetical model in figure 1 were GFI $=0.927$, NFI $=0.948, \quad$ CFI $=0.952, \quad$ IFI $=0.952, \quad$ TLI $=0.945$, RMSEA $=0.057$, RMR $=0.085$, and AGFI $=0.910$, all of which approached the recommended values and showed that the model fitted well. table 6 summarises the results of the direct and indirect effect of the model.

The edge between the dimensions in figure 1 represents the direct relationship. The direct effect of a dimension on another dimension is equal to the regression coefficient of the two dimensions. Based on figure 1, job satisfaction had a direct effect on turnover intention $(\gamma=-1.061$, $t$ value $=-22.734$ ), which supports Hypothesis 1 . A minus symbol before a coefficient represents a negative effect, for example, higher job satisfaction led to lower turnover 
Table 4 Item scores in job satisfaction, work stress, work-family conflict, and turnover intention

\begin{tabular}{|c|c|c|c|}
\hline Items & Mean \pm SD & Items & Mean \pm SD \\
\hline Job satisfaction* & $3.93 \pm 1.00$ & Work-family conflict* & $3.65 \pm 0.94$ \\
\hline Colleagues & $4.71 \pm 1.10$ & Work keeps me from family activities & $3.85 \pm 1.19$ \\
\hline The work itself & $4.39 \pm 1.33$ & $\begin{array}{l}\text { Time I devote to job keeps me from participating in } \\
\text { household activities }\end{array}$ & $3.93 \pm 1.14$ \\
\hline Promotions & $3.73 \pm 1.43$ & Miss family activities due to work & $3.93 \pm 1.11$ \\
\hline Remunerations & $3.03 \pm 1.48$ & Problem-solving behaviours make no sense at home & $3.69 \pm 1.12$ \\
\hline Environment & $3.56 \pm 1.45$ & $\begin{array}{l}\text { Behaviour that is effective and necessary at work } \\
\text { would be counterproductive at home }\end{array}$ & $3.30 \pm 1.08$ \\
\hline Facility & $3.41 \pm 1.39$ & $\begin{array}{l}\text { Behaviours make me effective at work do not help me } \\
\text { to be a better parent or spouse }\end{array}$ & $3.48 \pm 1.23$ \\
\hline Current job & $3.93 \pm 1.31$ & Too frazzled to participate in family activities & $3.62 \pm 1.21$ \\
\hline Superiors & $4.66 \pm 1.25$ & Drain prevents me from contributing to family & $3.51 \pm 1.25$ \\
\hline Work stress* & $4.17 \pm 1.17$ & $\begin{array}{l}\text { Owing to the pressures from work, I do not want to do } \\
\text { favourite things at home }\end{array}$ & $3.55 \pm 1.26$ \\
\hline Feel great pressure from work & $4.73 \pm 1.21$ & Turnover intention* & $2.71 \pm 1.31$ \\
\hline Feel a high level of tension from work & $4.91 \pm 1.19$ & Thought of leaving the organisation you served now & $2.79 \pm 1.46$ \\
\hline Trouble falling asleep because of work & $3.62 \pm 1.55$ & Thought of leaving this industry & $3.01 \pm 1.61$ \\
\hline \multirow[t]{2}{*}{ Feel nervous because of work } & $3.52 \pm 1.53$ & Looking for a new job recently & $2.83 \pm 1.56$ \\
\hline & & Looking for a new job next year & $2.21 \pm 1.35$ \\
\hline
\end{tabular}

${ }^{*}$ The overall perception of the four dimensions mentioned in table 4 for each respondent was the mean scores of the corresponding items.

Table 5 Results of the significant variables by the binary regression

\begin{tabular}{|c|c|c|c|c|c|}
\hline $\begin{array}{l}\text { Explanatory } \\
\text { variables }\end{array}$ & OR $(95 \% \mathrm{Cl})$ & $\mathbf{p}$ & Explanatory variables & OR $(95 \% \mathrm{Cl})$ & $\mathbf{p}$ \\
\hline $\begin{array}{l}\text { Hours worked per } \\
\text { week }\end{array}$ & & & \multicolumn{3}{|l|}{ Job satisfaction } \\
\hline $0 \sim 40$ & 1 & & Promotions & 0.836 (0.769 to 0.908$)$ & $<0.001$ \\
\hline $41 \sim 56$ & 1.374 (1.097 to 1.721$)$ & 0.006 & Remunerations & 0.896 (0.825 to 0.973$)$ & 0.009 \\
\hline $57 \sim$ & 1.174 (0.904 to 1.525$)$ & 0.228 & Current job & 0.628 (0.573 to 0.688$)$ & $<0.001$ \\
\hline Urban/rural area & & & Superiors & 0.894 (0.825 to 0.968$)$ & 0.006 \\
\hline Urban & 1 & & \multicolumn{3}{|l|}{ Work stress } \\
\hline Rural & 1.269 (1.045 to 1.541$)$ & 0.016 & $\begin{array}{l}\text { Trouble falling asleep } \\
\text { because of work }\end{array}$ & 1.140 (1.034 to 1.256$)$ & 0.008 \\
\hline Type of institution & & & Nerves caused by work & 1.480 (1.339 to 1.636$)$ & $<0.001$ \\
\hline Hospital & 1 & & \multicolumn{3}{|l|}{ Work-family conflict } \\
\hline $\begin{array}{l}\text { Community health } \\
\text { service centre }\end{array}$ & 1.353 (1.058 to 1.731$)$ & 0.016 & \multirow{2}{*}{$\begin{array}{l}\text { The behaviour that is effective } \\
\text { and necessary at work would } \\
\text { be counterproductive at } \\
\text { home }\end{array}$} & \multirow[t]{2}{*}{1.174 (1.054 to 1.308$)$} & \multirow[t]{2}{*}{0.004} \\
\hline $\begin{array}{l}\text { Health clinics } \\
\text { Age }\end{array}$ & $1.482(1.154$ to 1.904$)$ & 0.002 & & & \\
\hline 19 34 & 1 & & \multirow{3}{*}{$\begin{array}{l}\text { The behaviour makes me } \\
\text { effective at work do not help } \\
\text { me to be a better parent or } \\
\text { spouse }\end{array}$} & \multirow[t]{3}{*}{1.176 (1.060 to 1.305$)$} & \multirow[t]{3}{*}{0.002} \\
\hline $35 \sim 44$ & $1.030(0.842$ to 1.260$)$ & 0.772 & & & \\
\hline $45 \sim$ & & & & & \\
\hline & & & $\begin{array}{l}\text { Owing to the pressures from } \\
\text { work, I do not want to do } \\
\text { favourite things at home }\end{array}$ & 1.171 (1.062 to 1.291$)$ & 0.002 \\
\hline Cox \& Snell $R^{2}$ & 0.296 & & Nagelkerke $R^{2}$ & 0.421 & \\
\hline
\end{tabular}




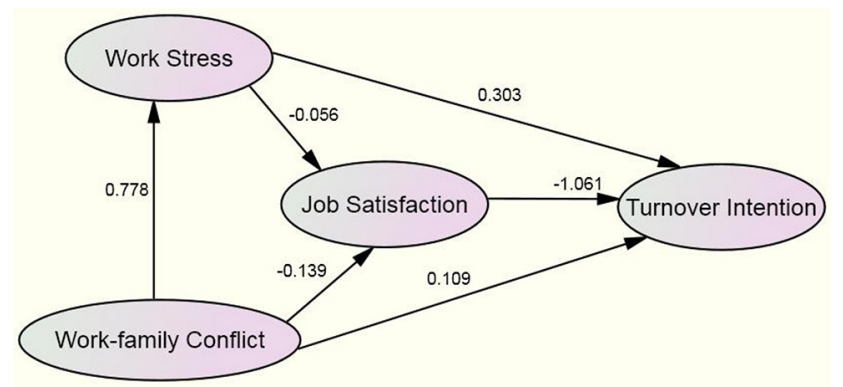

Figure 1 The hypothetical model used in the study.

intention. Work stress had a direct effect on turnover intention $(\gamma=0.303, t$ value $=18.940)$ and job satisfaction $(\gamma=-0.056, t$ value $=-5.948)$, which supports Hypotheses 2 and 3. Further, work-family conflict had a direct effect on turnover intention $(\gamma=0.109, t$ value $=5.409)$, job satisfaction $(\gamma=-0.139, t$ value $=-11.026)$, and work stress $(\gamma=0.778, t$ value $=35.797)$, which supports Hypotheses 4, 5 , and 6 , respectively. It should be noted that the absolute value of the direct effect of job satisfaction on turnover intention was much larger than the effect of work stress and work-family conflict on turnover intention.

Indirect effects were also evaluated in this study. The indirect effect of a dimension on another dimension was equal to the product of the regression coefficients of the directly connected dimensions. Therefore, the indirect effect of work stress on turnover intention was equal to the product of the regression coefficient of work stress and job satisfaction and the regression coefficient of job satisfaction and turnover intention. The indirect effect of work stress on turnover intention was found to be significant at 0.060 $(-0.056 \times-1.061)$. Moreover, the indirect effect of workfamily conflict on turnover intention was significant at 0.430 $(-0.139 \times-1.061+0.778 \times 0.303+0.778 \times-0.056 \times-1.061)$, which was larger than its direct effect on turnover intention.

table 6 shows that the total effect of job satisfaction, work stress, and work-family conflict on turnover intention was $-1.061,0.363$ and 0.539 , respectively. The impact of job satisfaction on turnover intention was the largest. The squared multiple correlations value was 0.555 , which means that the established SEM explained $55.5 \%$ of the total variance of turnover intention.

\section{DISCUSSION}

\section{Turnover intention}

Although different measuring instruments for turnover intention had been used in the literature, the mean scores and the percentages of high perception of turnover intention could be used as a reference to the potential turnover behaviour. ${ }^{14}$ In our study, the scores for the four items in the turnover intention were smaller than (ie, 2.79, 2.83, 2.21) or close to (3.01) the median 3 in the six range scales, that is, 1 - strongly disagree, 2 - disagree, 3 - slightly disagree, 4 - slightly agree, 5 - agree, 6 - strongly agree and the mean score of overall perception of turnover intention was 2.71 (lower than slightly disagree). The overall perception of turnover intention exceeded 'I prefer to stay' (score 2) and approached 'I have half a mind to stay' (score 3). A score greater than 3.5 is considered a high score, the percentages of higher scores for each item of turnover intention were $30.3 \%, 38.3 \%, 33.7 \%$ and $16.9 \%$, respectively. Based on the results, $2697(75.7 \%)$ participants had low turnover intention, but 866 (24.3\%) participants had high turnover intention. About a quarter of physicians had high turnover intention in Guangdong Province compared with the investigations made in Hubei Province (eg, 36.8\% of the village doctors had turnover intention in Xiangyang City, ${ }^{19}$ turnover intention to be 3.18 out of $5^{20}$ ); the turnover intention in Guangdong was relatively smaller. However, the turnover intention of physicians in Guangdong was still higher than that in Taiwan. ${ }^{21}$ Generally, for the areas with better medical welfare, such as Finland ${ }^{23}{ }^{24}$ and Madrid, ${ }^{25}$ the turnover intention of physicians was low. However, due to poor working conditions and serious security concerns, the turnover intention of Iraqi doctors was very high (55.2\%). ${ }^{15}$ Based on our study, more attention should be paid to the physicians in Guangdong to reduce their turnover intention.

Studies conducted in other countries or areas mentioned a series of influencing factors of turnover intention. In China, Fang et $a l^{19}$ showed that income satisfaction, 'the way organisation policies are put into practice', 'my pay' and 'the amount of work I do', promotions and the work environment had an impact on turnover intention of village doctors. Zhang and Feng's ${ }^{20}$ study disclosed that several dimensions of both job satisfaction and burnout syndrome were influencing factors of physicians' turnover intention. Liu and Quan $^{27}$ revealed organisational commitment had an indirect effect on the turnover intention of doctors through the mediating effect of job satisfaction and self-expectation. In other countries, Heponiemi et a $t^{23}$ performed two studies that showed that physicians who had on-call duty, high demands, and experienced physical violence were more likely to have higher turnover intention. Moreno-jiménez et a $l^{25}$ carried

Table 6 Effects of factors on turnover intention $(p<0.05)$

\begin{tabular}{lclll}
\hline Turnover intention & Job satisfaction & Work stress & Work-family conflict & $\begin{array}{l}\text { Squared multiple } \\
\text { correlations }\end{array}$ \\
\hline Direct effect & -1.061 & 0.303 & 0.109 & 0.555 \\
Indirect effect & - & 0.060 & 0.430 & \\
Total effect & -1.061 & 0.363 & 0.539 & \\
\hline
\end{tabular}


out a study indicating commitment had a negative effect, and difficult patients had a positive effect on turnover intention of physicians. Tziner $e t a l^{26}$ showed that work stress and burnout had a positive effect on turnover intention and job satisfaction had a negative effect on turnover intention. Income satisfaction, promotion, job satisfaction and work stress were also mentioned in our study and the results were in line with the previous studies.

\section{Socio-demographic characteristics}

According to the models of binary logistic analysis, hours worked per week, working in an urban/rural area, type of institution and age were four important socio-demographic variables influencing the turnover intention of physicians. The results indicated that turnover intention was related to hours worked per week. Physicians who worked 41 56hours per week had a 1.374 times higher turnover intention than those who worked up to 40 hours per week. The model revealed the more hours the physicians worked, the higher turnover intention they would have. The result was consistent with the findings by Jadoo, ${ }^{15}$ Ruan $^{65}$ and Steinmetz. ${ }^{66}$ Long working time might cause fatigue, tension and burnout, which had an indirect effect on turnover intention. ${ }^{6768}$ Especially, on-call physicians faced enormous work stress. A study revealed that work stress alone and working on-call combined with high work stress might induce thoughts of leaving the job. ${ }^{23}$ The results also showed that the turnover intention of physicians who worked in rural areas was higher than that of physicians who worked in urban areas. The results were consistent with the findings of Lagerlund et al. ${ }^{69}$ Physicians prefer to stay in urban areas because of better welfare treatment, work environment and social resources. A serious consequence of the Healthcare reform was the brain drain from basic medical institutions because of the reduction of income and limitations of clinical autonomy caused by the essential drug list. ${ }^{49}$ Similar results were reported by other studies. ${ }^{70}$ Meanwhile, physicians who worked in health clinics had a 1.482 times higher turnover intention than those who worked in hospitals. Physicians who worked in community health service centres had a 1.353 times higher turnover intention than those who worked in hospitals. The results are similar to those on medical personnel reported by Ruan $^{65}$ and Song. ${ }^{70}$ Ruan et a $l^{65}$ mentioned that non-indigene, low-welfare treatment, a big gap between actual and expected income, low job satisfaction, and few career development opportunities caused high turnover intention in primary medical institutions. Besides, our research also revealed that younger physicians had a higher turnover intention, which was in accordance with the results reported by Heponiemi et $_{\text {al. }}{ }^{72}$

\section{Job satisfaction}

Under the control of socio-demographic variables, the results of our model indicated that the four job satisfaction items including promotion, remuneration, current job and superiors had a significant impact on turnover intention. The results were consistent with previous studies in China ${ }^{14}$ and other countries. ${ }^{73-75}$ According to a study conducted by $\mathrm{Gu},{ }^{14}$ not all dimensions of satisfaction had an effect on turnover intention. The empirical study ${ }^{14}$ undertaken in Shanghai found that promotions, remunerations, superiors, of the work itself and the total job satisfaction, had a negative effect on physicians who worked in tertiary hospitals in Shanghai. Lack of promotion opportunities may reduce efficiency, cut enthusiasm or even lead to the staff resignation. Some studies mentioned that an attractive remuneration was a key factor of job satisfaction. Low remunerations may lead to trouble in attracting and recruiting new staff. ${ }^{73}$ However, the salary reform which started in 2009 introduced a fixed basic salary and a performance bonus to replace the previous income sources. Physicians from poor areas might have a higher income and financial security, and those in wealthy areas might have serious income reduction after the reform. ${ }^{48} 49$ A more reasonable salary distribution system is needed to guarantee the remunerations of physicians. Other studies revealed that support from superiors and interactions with managers are important. Encouragement from superiors will result in better performance in the workplace. ${ }^{73}$ Physicians may have a turnover intention because of lack of trust and respect from their superiors. ${ }^{75} 76$

\section{Work stress}

The results of the logistic regression also revealed that trouble falling asleep because of work and nerves caused by work were significant predictors of turnover intention. Work stress positively influenced turnover intention, which was consistent with other studies. ${ }^{31} 39$ 77-83 The studies from different areas, different industries and different populations presented the same results. Trouble falling asleep led to a higher turnover intention. As an item of working stress, trouble falling asleep meant the pressure was relatively high, and physical health problems began to appear. Cary mentioned that mental health problems and lack of mental well-being at work were related to work stress, and they could result in a reduction of employees' productivity. ${ }^{79}$ Matthias et al mentioned that work stress not only caused a decrease in work ability and mental health problems but also resulted in problems of physical function. ${ }^{80}$ Health problems and lack of rest might be the reasons for a higher turnover intention. Another item caused by work was mentioned in a study undertaken by Liu et al. ${ }^{81}$ The study indicated that acts of violence which happened in hospitals would cause fear, nervous problems, and psychological burden, eventually leading to departure. However, after the Healthcare reform, significant increases in insurance coverage were accompanied by increased use of Healthcare. ${ }^{82}$ Healthcare became more accessible, so that the workload of physicians had increased significantly, especially in secondary and tertiary hospitals. ${ }^{48}{ }^{49}$ It is necessary to formulate policies to reduce the workload of physicians. 


\section{Work-family conflict}

The model also showed work-family conflict positively influenced turnover intention, which had also been mentioned in other studies. ${ }^{45}{ }^{81-84}$ Stefanie et al revealed that women who suffered from higher work-family conflict showed higher family-related stress. ${ }^{85}$ We could regard work-family conflict as a stressor. Work characteristics, such as night shifts, minimal control over work hours and unpredictable scheduling requirements are important stressors which are positively related to work-family conflict. ${ }^{45} 86$ These work characteristics are applicable to physicians. Hence, there is a positive relationship between work-family conflict and turnover intention with work stress as a mediator. Some studies ${ }^{7787}$ mentioned that work-family conflict had indirect effects on turnover intention, but had no direct impact on turnover intention. As the results showed, the indirect effect is much greater than the direct effect, so the small samples of other studies did not have enough power to detect the direct effect.

According to the empirical analytical results using SEM, work-family conflict of physicians directly affected turnover intention and also indirectly influenced turnover intention through work stress and job satisfaction. Meanwhile, work stress of physicians not only directly affected turnover intention but also indirectly influenced turnover intention through job satisfaction, which was in accordance with the results mentioned in other studies. ${ }^{89}$ Besides, the results using SEM also indicated that job satisfaction had a direct effect on turnover intention. This was consistent with the results of binary logistic regression and many other studies. ${ }^{162688}$

Some of the factors which influence the turnover intention of physicians such as working in an urban/rural area, type of institution, and age cannot be resolved by health system reform or policy formulation. However, reduction of working hours, increasing income, providing opportunities for development and training may be useful to reduce turnover intention of physicians.

The main limitation of this study was that, as a cross-sectional design, the study had limited ability to infer causal relationships between job satisfaction, work stress, workfamily conflict and turnover intention. The second limitation was that the instrument in this study was not a commonly used international scale. They were developed according to the national conditions of China, so it may not be suitable for other countries and areas.

\section{CONCLUSIONS}

The mean score of the overall perception of turnover intention of physicians working in Guangdong was 2.71 (neutral) on a six-point scale ( $1=$ strongly disagree, $6=$ strongly agree). A total of $75.7 \%$ of participants had low turnover intention, and $24.3 \%$ of participants had a high turnover intention. It is concluded that turnover intention of physicians was significantly associated with job satisfaction, work stress, work-family conflict and socio-demographic factors, including hours worked per week, working in an urban/rural area, type of institution, and age. The results may be useful for policy makers and health administrators wishing to stop more doctors leaving the profession, especially in rural areas and basic medical institutions. To achieve the goal of reducing turnover intention, the appropriate policies should be developed focusing on job satisfaction, work stress and work-family conflict, especially job satisfaction. Administrative departments should pay more attention to the physicians who work in rural areas and basic medical institutions. Measures should be taken to reduce working hours, raise income, provide opportunities for career development and training, encourage support of healthcare staff from senior managers, reduce work stress and balance work-family conflict.

\section{Author affiliations}

${ }^{1}$ Sun Yat-sen University, Guangdong Key Laboratory of Health Informatics, Health Information Research Center, Department of Medical Statistics and Epidemiology, School of Public Health, Guangzhou, Guangdong, China

${ }^{2}$ School of Computer Science and Technology, Guangdong University of Technology, Guangzhou, Guangdong, China

${ }^{3}$ Government Affairs Service Center of Health Department of Guangdong Province, Guangzhou, Guangdong, China

${ }^{4}$ Department of Cardiology, the First Affiliated Hospital, Sun Yat-sen University, Guangzhou, Guangdong, China

Acknowledgements We are thankful to all the Healthcare staff who participated in the study.

Contributors $\mathrm{YL}$ and X-MH drafted the manuscript, performed statistical analyses and involved in the interpretation of the data. $X-D Z$ and $P G$ performed statistical analyses. X-LH, L-FF, WH, and LC played a major role in the field survey. $\mathrm{H}-\mathrm{CZ}$ and $\mathrm{Y}-\mathrm{TH}$ made a substantial contribution to the interpretation of the data and involved in revising manuscript. All authors read and approved the final manuscript.

Funding The research was financially supported by the Health Department of Guangdong Province, China.

Competing interests None declared.

Patient consent No patients involved in this study.

Ethics approval Health Department of Guangdong Province, China.

Provenance and peer review Not commissioned; externally peer reviewed.

Data sharing statement Original data is available on request. Please contact the corresponding author for further information.

Open Access This is an Open Access article distributed in accordance with the Creative Commons Attribution Non Commercial (CC BY-NC 4.0) license, which permits others to distribute, remix, adapt, build upon this work non-commercially, and license their derivative works on different terms, provided the original work is properly cited and the use is non-commercial. See: http://creativecommons.org/ licenses/by-nc/4.0/

(C) Article author(s) (or their employer(s) unless otherwise stated in the text of the article) 2017. All rights reserved. No commercial use is permitted unless otherwise expressly granted.

\section{REFERENCES}

1. Health Department of Guangdong Province. The number of health personnel from 2009 to 2013 in Guangdong Province [internet] http:// www.gdwst.gov.cn/a/wstj/2014041711599.html.

2. China health statistics yearbook [internet]. $2010 \mathrm{http} / / / \mathrm{www} . \mathrm{nhfpc}$. gov.cn/htmlfiles/zwgkzt/ptjnj/year2010/index2010.html.

3. United States of America statistics summary [internet]. $2002 \mathrm{http} / / /$ apps.who.int/gho/data/node.country.country-USA. 
4. Chao MC, Jou RC, Liao CC, et al. Workplace stress, job satisfaction, job performance, and turnover intention of health care workers in rural Taiwan. Asia Pac J Public Health 2015;27:NP1827-NP1836.

5. March JG, Simon HA. Organizations. New York: Wiley, 1958.

6. Mobley WH. Intermediate linkages in the relationship between job satisfaction and employee turnover. Journal of Applied Psychology 1977;62:237-40.

7. Mobley WH, Horner SO, Hollingsworth AT. An evaluation of precursors of hospital employee turnover. J Appl Psychol 1978;63:408-14.

8. Mobley WH, Griffeth RW, Hand HH, et al. Review and conceptual analysis of the employee turnover process. Psychological Bulletin 1979;86:493-522.

9. Bluedorn AC. A unified model of turnover from organizations. Human Relations 1982;35:135-53

10. Sheridan JE, Abelson MA. Cusp catastrophe model of employee turnover. Academy of Management Journal 1983;26:418-36.

11. Lee TW, Mitchell TR. An alternative approach: the unfolding model of voluntary employee turnover. Academy of Management Review 1994;1:51-89.

12. Price JL. The study of turnover. lowa State University Press: Ames, 1977.

13. Price JL. The development of a causal model of voluntary turnover. lowa State University Press: Ames, 2000.

14. Gu St, Huang QM, Chen ZHQ, et al. Relationship between job satisfaction and turnover intention among physicians from threegrade hospitals. Chinese Journal of Hospital Administration 2006:9:586-9.

15. Ali Jadoo SA, Aljunid SM, Dastan I, et al. Job satisfaction and turnover intention among iraqi doctors-a descriptive cross-sectional multicentre study. Hum Resour Health 2015;13:11.

16. Bonenberger $M$, Aikins $M$, Akweongo $P$, et al. The effects of health worker motivation and job satisfaction on turnover intention in Ghana: a cross-sectional study. Hum Resour Health 2014;12:43-54.

17. Li D, Yin WQ, Zhang $X Y$, et al. Investigation on turnover intention of medical staff in public hospitals and research of early-warning system's construction. Chinese Journal of Hospital Administration 2010;3:218-21.

18. Wang F, Gao Y. Doctor with high work stress (Chinese version). China Hospital CEO 2014;7:50-1.

19. Fang P, Liu X, Huang L, et al. Factors that influence the turnover intention of chinese village doctors based on the investigation results of Xiangyang City in Hubei Province. Int $J$ Equity Health 2014;13:7-24.

20. Zhang $Y$, Feng $X$. The relationship between job satisfaction, burnout, and turnover intention among physicians from urban state-owned medical institutions in Hubei, China: a cross-sectional study. BMC Health Serv Res 2011;11:235-47.

21. Tsai $\mathrm{YH}$, Huang N, Chien LY, et al. Work hours and turnover intention among hospital physicians in Taiwan: does income matter? BMC Health Serv Res 2016;16:1-8.

22. Waldman JD, Kelly F, Arora S, et al. The shocking cost of turnover in health care. Health Care Manage Rev 2004;29:2-7.

23. Heponiemi T, Presseau J, Elovainio M. On-call work and physicians' turnover intention: the moderating effect of job strain. Psychol Health Med 2016;21:74-80.

24. Heponiemi T, Kouvonen A, Virtanen M, et al. The prospective effects of workplace violence on physicians' job satisfaction and turnover intentions: the buffering effect of job control. BMC Health Serv Res 2014;14:1-16.

25. Moreno-Jiménez B, Gálvez-Herrer M, Rodríguez-Carvajal R, et al. A study of physicians' intention to quit: the role of burnout, commitment and difficult doctor-patient interactions. Psicothema 2012;24:263-70.

26. Tziner A, Rabenu E, Radomski R, et al. Work stress and turnover intentions among hospital physicians: the mediating role of burnout and work satisfaction. Revista de Psicología del Trabajo y de las Organizaciones 2015;31:207-13.

27. Liu RM, Quan P. Relation between doctor organizational commitment and turnover intention: the mediating role of job satisfaction and self - expectation. Chinese General Practice 2016;19:317-21.

28. Lambert EG, Lynne Hogan N, Barton SM. The impact of job satisfaction on turnover intent: a test of a structural measurement model using a national sample of workers. The Social Science Journal 2001;38:233-50.

29. Coomber B, Barriball KL. Impact of job satisfaction components on intent to leave and turnover for hospital-based nurses: a review of the research literature. Int J Nurs Stud 2007;44:297-314.

30. Jamal M. Burnout among Canadian and Chinese employees: a cross-cultural study. European Management Review 2005;2:224-30.
31. Arshadi N, Damiri $\mathrm{H}$. The relationship of job stress with turnover intention and job performance: moderating role of OBSE. Procedia Social and Behavioral Sciences 2013;84:706-10.

32. Lu Y, Hu XM, Huang XL, et al. Job satisfaction and associated factors among healthcare staff: a cross-sectional study in Guangdong Province, China. BMJ Open 2016;6:1-9.

33. Wu S, Zhu W, Li H, et al. Workplace violence and influencing factors among medical professionals in China. Am J Ind Med 2012;55:1000-8.

34. Wu S, Li H, Zhu W, et al. Effect of work stressors, personal strain, and coping resources on burnout in Chinese medical professionals: a structural equation model. Ind Health 2012;50:279-87.

35. Jamal M. Relationship of job stress and Type-A behavior to employees' Job satisfaction, organizational commitment, psychosomatic health problems, and turnover motivation. Human Relations. 1990;43:727-38.

36. Harzer C, Ruch W. The relationships of character strengths with coping, work-related stress, and job satisfaction. Front Psychol 2015;6:1-12.

37. Mansoor M, Fida S, Nasir S. The impact of job stress on employee job satisfaction A Study on Telecommunication Sector of Pakistan. Journal of Business Studies Quarterly 2011;2:50-6.

38. Gray-Toft $P$, Anderson JG. Stress among hospital nursing staff: its causes and effects. Soc Sci Med A 1981;15:639-47.

39. Liu S, Onwuegbuzie AJ. Chinese teachers' work stress and their turnover intention. International Journal of Educational Research 2012;53:160-70.

40. $\mathrm{Kim} \mathrm{H}$, Kao D. A meta-analysis of turnover intention predictors among U.S. child welfare workers. Children and Youth Services Review 2014;47:214-23.

41. Han SS, Han JW, Choi EH. Effects of nurses' Job stress and work family conflict on turnover intention: focused on the mediating effect of coping strategies. Asian Women. 2015;31:1-20.

42. Greenhaus $\mathrm{JH}$, Beutell NJ. Sources of conflict between work and family roles. Academy of Management 1985;76.

43. Voydanoff P. Integrating work and family: challenges and choices for a changing world. Family Relations 1999;2:215.

44. Özbağ GK, Ceyhun Gökçe Ciçek. Does job satisfaction mediate the relationship between Work-family conflict and turnover? A study of Turkish marine pilots. Procedia - Social and Behavioral Sciences 2014:140:643-9.

45. Blomme RJ, Van Rheede A, Tromp DM. Work-family conflict as a cause for turnover intentions in the hospitality industry. Tourism and Hospitality Research 2010;10:269-85.

46. Post C, DiTomaso N, Farris GF, et al. Work-family conflict and turnover intentions among scientists and engineers working in R\&D. Journal of Business and Psychology 2009;24:19-32.

47. Armstrong GS, Atkin-Plunk CA, Wells J. The relationship between Work-Family conflict, correctional officer job stress, and job satisfaction. Crim Justice Behav 2015;42:1066-82.

48. Wu D, Wang Y, Lam KF, et al. Health system reforms, violence against doctors and job satisfaction in the medical profession: a cross-sectional survey in Zhejiang Province, Eastern China. BMJ Open 2014:4:1-10.

49. Zhou XD, Li L, Hesketh T. Health system reform in Rural China: voices of healthworkers and service-users. Soc Sci Med 2014:117:134-41.

50. Guan X, Liang H, Xue $\mathrm{Y}$, et al. An analysis of China's national essential medicines policy. J Public Health Policy 2011;32:305-19.

51. Feng XT. Sociological research methods [M]. Beijing: Renmin University Press, 2005

52. Gong YL, Feng XS. Health services research [M]. Shanghai: Fudan University Press, 2003.

53. National Bureau of Statistics of China. Department investigation project examination and approval notice [Internet] $2013 \mathrm{http}: / / \mathrm{www}$. stats.gov.cn/tjfw/bmdcxmsp/bmdcspgg/201308/t20130807_60433. html.

54. Smith PC, Kendall LM, Hulin CL. The measurement of satisfaction in work and retirement. Chicago: Rand McNally, 1969.

55. Hassard J, Cox T, et al. Mental health promotion in the workplace- $A$ good practice report. Luxembourg: Publications Office of the European Union, 2013

56. Cammann C, Fichman M, Jenkins D, et al. The Michigan organizational assessment questionnaire. Ann Arbor, Michigan: Unpublished Manuscript, University of Michigan, 1979.

57. Mobley WH. Intermediate linkages in the relationship between job satisfaction and employee turnover. Journal of Applied Psychology 1977;62:237-40.

58. Carlson DS, Kacmar KM, Williams LJ. Construction and initial validation of a multidimensional measure of Work-Family Conflict. Journal of Vocational Behavior 2000;56:249-76. 
59. Thomason DL, Feng D. Reliability and validity of the physical education activities Scale. J Sch Health 2016;86:424-34.

60. Munro BH. Statistical methods for Health Care Research. 5th ed. Philadelphia, PA: Lippincott Williams \& Wilkins2005.

61. Tekin A, Polat E. A scale for e-content preparation skills: development, validity and reliability. Eurasian Journal of Educational Research 2016;62:161-78.

62. Hu Li-tze, Bentler PM. Cutoff criteria for fit indexes in covariance structure analysis: conventional criteria versus new alternatives. Structural Equation Modeling: A Multidisciplinary Journal 1999;6:1-55.

63. Gliem RR, Calculating GJA. Interpreting, and reporting Cronbach's alpha reliability coefficient for Likert-type scales. Midwest Researchto-Practice Conference in Adult, Continuing, and Community Education 2003.

64. Ullman JB. Structural equation modeling. In: Tabachnick IBG, Fidell LS, eds. Using multivariate statistics (4th ed). Needham Heights, MA: Allyn \& Bacon, 2001.

65. Ruan ZZ. Turnover intention and correlations of health personnel at country and township levels in Yunnan. Kunming Medical University 2013. MD thesis.

66. Steinmetz S, de Vries DH, Tijdens KG. Should I stay or should I go? the impact of working time and wages on retention in the health workforce. Hum Resour Health 2014;12:23-34.

67. Huang SR. The influence of long-time working for resident doctors. Hospital Management Forum 1989;3:130-1.

68. Herda DN, Lavelle JJ. The Auditor-Audit firm relationship and its effect on burnout and turnover intention. Accounting Horizons 2012;26:707-23.

69. Lagerlund $M$, Sharp L, Lindqvist $R$, et al. Intention to leave the workplace among nurses working with Cancer patients in acute care hospitals in Sweden. Eur J Oncol Nurs 2015;19:629-37.

70. Song KM. Study on turnover intention and job preference of primary health workers in five provinces of China. Shandong University 2014. MD thesis.

71. Jing LM. Study on the status quo of Chinese human resource management of township health centers and community health facilities. Shandong University 2008.

72. Heponiemi T, Kouvonen A, Vänskä J, et al. The association of distress and sleeping problems with physicians' intentions to change profession: the moderating effect of job control. $J$ Occup Health Psychol 2009;14:365-73.

73. Ahmad T, Riaz A. Factors affecting turn-over intentions of doctors in public sector medical colleges and hospitals. Interdisciplinary Journal of Research in Business 2011:1:57-66.

74. Shields MA, Ward M. Improving nurse retention in the National Health Service in England: the impact of job satisfaction on intentions to quit. J Health Econ 2001;20:677-701.
75. Alasmari HAM, Douglas C. Job satisfaction and intention to leave among critical care nurses in Saudi Arabia. Middle East Journal of Nursing 2011;6:3-12.

76. Laschinger HK, Finegan J. Using empowerment to build trust and respect in the workplace: a strategy for addressing the nursing shortage. Nurs Econ 2005;23:6-13.

77. Pradana A, Salehudin I. Work overload and turnover intention of junior auditors in greater Jakarta, Indonesia. The South East Asian Journal of Management 2015;9:108-24.

78. Wong CA, Spence Laschinger HK. The influence of frontline manager job strain on burnout, commitment and turnover intention: a cross-sectional study. Int J Nurs Stud 2015;52:1824-33.

79. Cooper CL. Mental health and well being at work: the disposal workforce. Int J Public Health 2008:53:225-6.

80. Bethge M, Radoschewski FM. Adverse effects of effort-reward imbalance on work ability: longitudinal findings from the German sociomedical panel of employees. Int J Public Health 2012;57:797-805.

81. Liu J. Influence of work-family conflict, job stress on turnover intention in outpatient pediatric nurses. Shandong University 2013. MD thesis.

82. Meng Q, Xu L, Zhang Y, et al. Trends in access to health services and financial protection in China between 2003 and 2011: a crosssectional study. Lancet 2012;379:805-14.

83. $\mathrm{Kim} \mathrm{H}$, Kao D. A meta-analysis of turnover intention predictors among U.S. child welfare workers. Children and Youth Services Review 2014;47:214-23.

84. Simon M, Kümmerling A, Hasselhorn H-M, et al. Work-Home conflict in the European nursing profession. Int J Occup Environ Health 2004;10:384-91.

85. Sperlich S, Geyer S. The impact of social and family-related factors on women's stress experience in household and family work. Int $J$ Public Health 2015;60:375-87.

86. Cooklin AR, Giallo R, Strazdins L, et al. What matters for working fathers? Job characteristics, work-family conflict and enrichment and fathers' postpartum mental health in an Australian cohort. Soc Sci Med 2015;146:214-22.

87. Han SS, Han JW, An YS, Ys A, et al. Effects of role stress on nurses' turnover intentions: the mediating effects of organizational commitment and burnout. Jpn J Nurs Sci 2015;12:287-96.

88. Chen M-L, Su Z-Y, Lo C-L, et al. An empirical study on the factors influencing the turnover intention of dentists in hospitals in Taiwan. Journal of Dental Sciences 2014;9:332-44.

89. Tao $\mathrm{H}$, Ellenbecker $\mathrm{CH}$, Wang $\mathrm{Y}$ et al. Original Article: examining perception of job satisfaction and intention to leave among ICU nurses in China. International Journal of Nursing Sciences 2015;2:140-8. 